\title{
CHEMICAL COMPOSITION, ANTIBACTERIAL AND MODULATORY ACTION OF THE ESSENTIAL OIL OF Croton rhamnifolioides LEAVES Pax and Hoffman
}

\author{
COMPOSIÇÃO QUIMMICA, AÇÃO ANTIBACTERIANA E MODULADORA DO \\ ÓLEO ESSENCIAL DAS FOLHAS DE Croton rhamnifolioides Pax and Hoffman
}

\begin{abstract}
Cinara Soares VIDAL ${ }^{1}$; Cícera Datiane Morais OLIVEIRA-TINTINO ${ }^{1}$; Saulo Relison TINTINO $^{3}$; Hericka Bruna Figueiredo GALVAO ${ }^{4}$; José Galberto Martins da COSTA ${ }^{2}$; Henrique Douglas Melo COUTINHO ${ }^{*}$; Irwin Rose Alencar de MENEZES ${ }^{1}$

1. Department of Biological Chemistry, Laboratory of Pharmacology and Molecular Chemistry, Regional University of Cariri-URCA, Crato-CE, Brazil; 2. Department of Biological Chemistry, Laboratory of Research in Natural Product, Regional University of Cariri URCA, Crato, CE, Brazil; 3. Department of Biological Chemistry, Laboratory of Microbiology and Molecular Biology, Regional University of Cariri, URCA, Crato-CE, Brazil.; 4. St George's, University of London, Cranmer Terrace, London - SW17 0RE
\end{abstract}

\begin{abstract}
The species Croton rhamnifolioides is a shrub popularly known as "quebra faca", utilized in teas or infusions for the treatment of gastrointestinal disorders as ulcers, gastric discomfort, vomiting and hemorrhagic diarrhea. This work has as its main objective to evaluate the chemical composition of the essential oil of the Croton rhamnifolioides leaves (EOC), antibacterial activity and modulatory activity of antibiotic resistance, against bacterial strains of Escherichia coli, Staphylococcus aureus and Pseudomonas aeruginosa and, and antifungal activity against Candida albicans, Candida krusei and Candida tropicalis. The chemical composition was determined through chromatography with a gas phase coupled with mass spectrometry (CG/MS), whereas antimicrobial activity and modulation were determined by microdilution assay. The chemical composition of the oil revealed 21 compounds, with the major compounds being spathulenol (22.46\%) and 1,8-cineol (18.32\%). The antimicrobial activity was not significant with MIC> $>1024 \mu \mathrm{g} / \mathrm{mL}$, however, was observed a synergistic interference when essential oil associated with the antibiotics aminoglycoside and $\beta$-lactam, and the antifungal polyene.
\end{abstract}

KEYWORDS: Croton rhamnifolioides. Modulation. Essential oil. Terpenes.

\section{INTRODUCTION}

The occurrence of resistance of pathogenic microorganisms has been increasingly documented around the world leading to a range of infections caused primarily by multi-resistant bacteria. The ever increasing consumption of antibiotics results in the resistance of bacterial populations causing a serious problem to the public health (BLAIR et al, 2014). With this, there is a growing recurrence to phytotherapy, where there is a search for new substances with antimicrobial activity, derived from natural products, which are easily available at smaller prices (SANTOS et al, 2011).

Recently, scientific studies have been confirming the activity of an increasing number of natural substances with antimicrobial properties, derived from extracts or essential oils from medicinal plants, in view of the growing demand for an antimicrobial that presents with a bigger spectrum of action, smaller toxicity, decreased cost and a small incidence of resistance (ALVARENGA, 2007; VICTORIA, 2010).

Many plant species of various Brazilian regions and biomes have been used as natural remedies by local populations in the treatment of several tropical diseases including schistosomiasis, leishmaniosis, malaria and fungal and bacterial infections (ALVES et al, 2000).

For example, some species of the Croton genus can be cited, whose studies have confirmed its anti-inflammatory, anti-ulcerogenic, antimutagenic, anti-estrogenic and hypoglycemic (ROSA et al, 2003), antinociceptive (OLIVEIRA et al, 2001), antifungal (SOUZA et al, 2006), antibacterial (SILVA et al, 2011; RODRIGUES et al, 2009), anti-leishmaniosis (ROSA et al, 2003), anti-Trypanosoma cruzi (CAMPOS et al, 2010), larvicide (LIMA et al, 2006) and as a central nervous system depressor (LAZARINI et al, 2000).

Within the species of this genus, Croton rhamnifolioides stands out Pax and Hoffman, belonging to the family Euphorbiaceous, popularly known as "Quebra faca". This plant is popularly utilized in the form of teas and infusions for the treatment of ulcers, stomachaches, gastric discomfort, vomiting and hemorrhagic diarrhea (RANDAU, 2001).

In this sense, the development of new studies that elucidate the action of natural remedies that possess antimicrobial action or that can attenuate the action of commercial pharmaceuticals 
are fundamental, since new substances obtained from plant species that present antimicrobial activity are a viable alternative, inexpensive and of easy access to the population.

With this in mind, the present work aimed to elucidate the antimicrobial potential, determine the Minimum Inhibitory Concentration (MIC) and modulatory activity of the essential oil from Croton rhamnifolioides (EOC) leaves, against the bacterial strains of Escherichia coli, Staphylococcus aureus, Pseudomonas aeruginosa and fungal strains of Candida albicans and Candida tropicalis, verifying its synergism in association with $\beta$-lactam, penicillin and aminoglycoside antibiotics, and polyene, nitroimidazol antifungals.

\section{MATERIAL AND METHODS}

The leaves from Croton rhamnifolioides are utilized in the production of the essential oil were collected from the Ecological Station of Aiuaba, South of Ceará. For the realization of this collection authorization from the Chico Mendes Institute of Biodiversity (ICMBio), the responsible body for the ELONA Araripe-Apodi, under number 34112-1, was obtained. The material was collected in the month of June of 2012.

The essential oil was obtained using a hydrodistillation system in a Clevenger type device. The fresh Croton rhamnifolioides leaves were placed in a $5 \mathrm{~L}$ glass flask with distilled water. After this period, the water-oil mixture obtained was separated, treated with anhydrous sodium sulphate, filtered and the oil maintained under refrigeration until analysis.

The analysis of the essential oil was made through chromatography with a gas phase coupled with mass spectrometry (CG/MS) in a Shimadzu GC MS-series QP2010 equipment with the programmed settings: capillary column Rtx-5MS with 30 meters length, $0.25 \mathrm{~mm}$ internal diameter and a film with $0.25 \mathrm{~mm}$ thickness; gas drag; Helium $(1.5 \mathrm{~mL} / \mathrm{m})$; Column temperature varied between $60^{\circ}$ $\mathrm{C}-180^{\circ} \mathrm{C}$ at $5^{\circ} \mathrm{C} / \mathrm{min}$ and afterwards between $180^{\circ}$ $\mathrm{C}-280^{\circ} \mathrm{C}$ at $10^{\circ} \mathrm{C} / \mathrm{min}$ (10minutes); Injector temperature of $250^{\circ} \mathrm{C}$; Injected volume of $1 \mathrm{~mL} / 5 \mathrm{~mL}$ of $\mathrm{CHCl}_{3}$; Split relationship (1:200) with the solvent cutting time of $2.5 \mathrm{~min}$. Digitalization velocity of $0.5 \mathrm{scan} / \mathrm{sec}$ of $\mathrm{m} / \mathrm{z} 40$ and 350 . The mass spectrometer was operated using $70 \mathrm{eV}$ ionization energy. Identification of the compounds was based on their fragmentation of the mass spectrum registered in the spectral library NIST Mass 08, in their indices of retention and comparison with published data.

The microorganisms utilized in the in vitro tests were obtained from the Microorganism Collection of the Mycology Laboratory of the Federal University of Paraíba (UFPB). The bacterial strains utilized were: Escherichia coli (EC-ATCC 25922 and EC 06), Staphylococcus aureus (SAATCC25923 and SA10) and Pseudomonas aeruginosa (PA-ATCC9027 and PA15). The fungal strains utilized were: Candida albicans (LM122), and Candida tropicalis (LM18). All the strains were maintained in an Agar infusion of the heart (HIA, Difco Laboratories Ltda.). Prior to the trials, the strains were cultivated for $18 \mathrm{~h}$ at $37^{\circ} \mathrm{C}$ in a heart and brain infusion broth (BHI, Difco Laboratories Ltda.). The bacterial origins and the antibiotic resistance profile of the multiresistant bacterial strains can be found in Table 1.

Table 1. Bacterial origin and antibiotic resistance profiles.

\begin{tabular}{lll}
\hline Bacteria & Origin & Resistance profile \\
Escherichia coli 06 (ECO6) & Urine culture & Ca, Cef, Cf, Cpm, Cro \\
Staphylococcus aureus 10 (SA10) & Rectal swab & Ca, Cef, Cf, Oxa, Pen, Amp, Amox, \\
& & Mox, Cip, Lev, Asb, Amc, Eri, Cla, Azi, \\
& Clin \\
Pseudomonasaeruginosa15(PA15) & Catheter tip & Cpm, Ctz, Imi, Cip, Ptz, Lev, Mer
\end{tabular}

Ast-Aztreonan; Ax - Amoxicillin; Amp - Ampicillin; Asb- Ampicillin + Sulbactam; Ami - Amikacin; Amox- Amoxicillin; AmcAmoxicillin + Ac. Clavulanic; Azi- Azithromycin; Ca -Cefadroxil; Cfc-Cefaclor; Cf-Cefalotin; Cef- Cephalexin; Com -Cefepime; Cla- Clarithromycin; Cro- Ceftriaxone; Ctz- Ceftazidime; Cip- Ciprofloxacin; Clo-Cloramphenicol; Clin- Clindamycin; ImiImipenem; Can - Kanamycin; Szt-Sulphametrim; Tet - Tetracycline; Tob- Tobramycin; Oxa- Oxacillin; Gen - Gentamycin; Lev Levofloxacin; Mer-Meropenem; Mox- Moxifloxacin; Neo - Neomycin; Para -Paramomycin; But -Butirosin; Sis -Sisomycin; Net Netilmicin; Pen - Penicillin; Ptz- Piperacillin + Tazobactam ( - ) Absence of resistance or irrelevant resistance.

To analyze the antibacterial and antifungal activity with the modulatory activity of the action of antibiotics and antifungals of the EOC a diverse range of drugs were utilized, the standard antibacterials being Amikacin, Amoxicillin, Gentamycin and Oxacillin and as antifungals the drugs Nystatin, Amphotericin and Benzoylmetronidazol were utilized. The drugs were 
obtained from the Laboratory Sigma Chemical Corp. (St Louis, MO, USA). All the solutions were prepared according to the CLSI (2008) recommendations.

Minimum inhibitory concentration (MIC)

The MIC (minimum inhibitory concentration) of the essential oil and of DMSO were determined in microtiter broth dilution assay (CLSI, 2008) using an inoculum of $100 \mu \mathrm{L}$ of each strain, in a concentration of $10^{5} \mathrm{CFU} / \mathrm{mL}$ and posteriorly suspended in BHI broth, in microtiter plates with 96 wells. $100 \mu \mathrm{L}$ of each sample solution were added to each well followed by 1:1 serial dilutions for both the essential oil and the DMSO control. Final concentrations of the oil range from 512 to $8 \mu \mathrm{g} / \mathrm{mL}$. The plates were incubated at $37^{\circ} \mathrm{C}$ for 24 hours, following this period, the reading was initiated by use of Resazurin in the bacterial test and turbidity of the medium for fungal analysis (CLSI, 2008). The MIC were defined as the minimum concentrations necessary for the inhibition of growth.

For the analysis of the essential oil action as a modifier of microbial resistance a MIC was determined with antimicrobial and antifungal drugs in the presence of the oil, in a sub-inhibitory concentration (MIC/8) of $128 \mu \mathrm{g} / \mathrm{mL}$ compared with the negative control DMSO and the positive control containing microorganisms. These presented themselves in a concentration of $10^{5} \mathrm{CFU} / \mathrm{mL}$, suspended in BHI broth, in microtiter plates with 96 wells. The further addition of the drugs proceeded with a quantity of $100 \mu \mathrm{L}$ distributed in each sterile microplate well, proceeding a 1:1 serial microdilution. The concentrations of the antibacterials and antifungals range from 2500 to 2.44 (5000 - $2.44 \mathrm{fla}) \mu \mathrm{g} / \mathrm{mL}$ and 512 to $8.0 \mu \mathrm{g} / \mathrm{mL}$ (1024 to 8) respectively (COUTINHO et al, 2008). The plates were incubated at $37^{\circ} \mathrm{C}$ for 24 hours after which the reading was made using the Resazurin in the plates with the antibiotic modulations and by observation of the turbidity in the plates with antifungals. The antibacterial and antifungal trials were made in triplicates and the results were expressed as a mean of the repeats.

\section{RESULTS AND DISCUSSION}

The chemical composition of the essential oil of the Croton rhamnifolioides leaves revealed 21 compounds, with the major components being spathulenol (22.46\%) and 1-8 cineol (18.32\%) (Table 2).

Table 2. Chemical composition (\%) of the essential oil of Croton rhamnifolioides.

\begin{tabular}{lll}
\hline Component & $(\%)$ & $\mathrm{RT}(\mathrm{min})$ \\
\hline Spathulenol & 22.46 & 38.79 \\
1,8 -cineol & 18.32 & 10.63 \\
o-cymene & 7.22 & 10.24 \\
$\alpha$-terpineol & 6.12 & 18.95 \\
trans-caryophyllene & 6.09 & 30.71 \\
$\gamma$-elemene & 4.45 & 34.59 \\
4-terpineol & 4.24 & 18.08 \\
$\delta$-cadineno & 3.92 & 41.9 \\
Sabinene & 2.81 & 7.99 \\
Linalol & 2.71 & 13.87 \\
Aromadendeno & 2.64 & 32.71 \\
$\alpha$-pinene & 2.14 & 6.56 \\
$\beta$-selinene & 2.09 & 34.2 \\
$\alpha$-humulene & 1.78 & 32.49 \\
Globulol & 1.77 & 39.87 \\
$\alpha$-cadinol & 1.66 & 42.59 \\
a-phellandrene & 1.63 & 9.35 \\
Caryophyllene oxide & 1.53 & 40.1 \\
Germacrene D & 1.09 & 33.8 \\
Isoborneol & 1.04 & 17.52 \\
$\beta$-elemene & 1 & 29.18 \\
\hline TOTAL & $\mathbf{9 6 . 7 1}$ & \\
\hline
\end{tabular}


Some compounds found in the essential oil of the Croton rhamnifolioides leaves are also found in various species of the Croton genus and possess scientifically proven biological activities. For example, spathulenol was majorly presented in Croton argyrophylloides demonstrating anticancer, immunomodulatory (ZIAEI et al, 2011), antibacterial (ALCÂNTARA et al, 2010), antiinflammatory and antioxidant activity (RAMOS et al, 2013). 1,8-cineol has also presented as a major compound of the essential oil of Hyptis martiusii, presenting gastro-protective activity (CALDAS et al, 2011). The species Croton sonderianus, Croton zehntneri, Croton nepetaefolius and Croton argyrophylloides were also identified where these demonstrate anti-inflammatory and antinociceptive action (AMARAL, 2004; MORAIS et al, 2006).

The chemical composition of the essential oil of Croton rhamnifolioides leaves is similar to the compounds identified in the same species by COSTA et al, (2013), presenting four constituent in common, identified by the present study: $\alpha$ pinene, sabinene, linalol and germacrene-D. However, in the study by this author the 1,8-cineol was identified as the major constituent. The chemical and pharmacodynamic differences of the essential oils of the same species from different locations are attributed to genetic variation between populations, the environment in which the plant is found or the genotype-environmental interactions (BOTREL et al, 2010).

The minimum inhibitory concentrations (MIC) of the product and of DMSO against the bacterial and fungal strains comparatively present the same results, revealing a MIC of $128 \mu \mathrm{g} / \mathrm{mL}$ for the bacteria and MIC of $64 \mu \mathrm{g} / \mathrm{mL}$ for the fungi, demonstrating no clinically relevant activity since the inhibitory concentration presented by the oil is the same as the for the solvent utilized (CLSI, 2008). The DMSO used in a concentration of up to $10 \%$ of the total solution is not capable of causing cytotoxicity, or of altering the membrane permeability (DA VIOLANTE et al, 2002).

In the modulation of bacterial resistance trials, a concentration of $16 \mu \mathrm{g} / \mathrm{mL}$ (MIC/8) was utilized, where the EOC demonstrated significant modulatory effects, potentiating the action of antibiotics of the aminoglycosides and $\beta$-lactam classes against Escherichia coli, Pseudomonas aeruginosa e Staphylococcus aureus (Figures 1 A, B and C).

In the EOC-Gentamicin association against Escherichia coli, there was a reduction in the media concentration of $248 \mu \mathrm{g} / \mathrm{mL}$ to $49.21 \mu \mathrm{g} / \mathrm{mL}$ $(80.15 \%)$, even though there was no change in phenotype because the bacteria continued being resistant. Escherichia coli is considered resistant to this drug at concentrations greater or equal to 8 $\mu \mathrm{g} / \mathrm{mL}$, while it is considered sensitive at concentrations lesser or equal to $4 \mu \mathrm{g} / \mathrm{mL}$ (CSLI, 2008). In the EOC-Oxacillin association against the same bacteria, the concentration went from 496.06 $\mu \mathrm{g} / \mathrm{mL}$ to $31 \mu \mathrm{g} / \mathrm{mL}$ (93.75\%) when compared to the antibiotic control. There was also no phenotypic difference, since the cutoff reduction of resistance equals a concentration that is greater or equal to 4 $\mu \mathrm{g} / \mathrm{mL}$, while the sensitivity represented values that are lesser or equal to $2 \mu \mathrm{g} / \mathrm{mL}$ (CSLI, 2008).

The synergistic activity of the essential oil against Pseudomonas aeruginosa was only significant when in association with Amoxicillin, where there was a reduction in media concentration from $19.52 \mu \mathrm{g} / \mathrm{mL}$ to $7.74 \mu \mathrm{g} / \mathrm{mL}$ symbolizing a potentiation of $60.34 \%$ for the synergistic effect in relation to the control antibiotic. It can also be observed an antagonistic action of the oil when associated with Amikacin, however, this did not present as clinically significant.

In the modulatory action against Staphylococcus aureus there was significant synergism in the EOC-Gentamicin association that presented a reduction in the media concentration from $15.49 \mu \mathrm{g} / \mathrm{mL}$ to $7.74 \mu \mathrm{g} / \mathrm{mL}$, an increase in activity of the antibiotic of $49.96 \%$. The bacteria continued being resistant since Staphylococcus aureus is considered resistant to this drug at concentrations greater or equal to $8 \mu \mathrm{g} / \mathrm{mL}$, while it is considered sensitive at concentrations lesser or equal to $4 \mu \mathrm{g} / \mathrm{mL}$ (CSLI, 2008). In the EOCOxacillin association, a reduction in concentration from $312.5 \mu \mathrm{g} / \mathrm{mL}$ to $39.06 \mu \mathrm{g} / \mathrm{mL}$ representing a 12.49 percentage point of synergism when compared to the control antibiotic. The EOC also presented an antagonistic action, although not significant, when in association with Amikacin. There was also no change in phenotype, since the cutoff resistance equals a concentration greater or equal to $4 \mu \mathrm{g} / \mathrm{mL}$, while the sensitivity is represented by values lesser or equal to $2 \mu \mathrm{g} / \mathrm{mL}$ of Oxacillin (CSLI, 2008). 
A

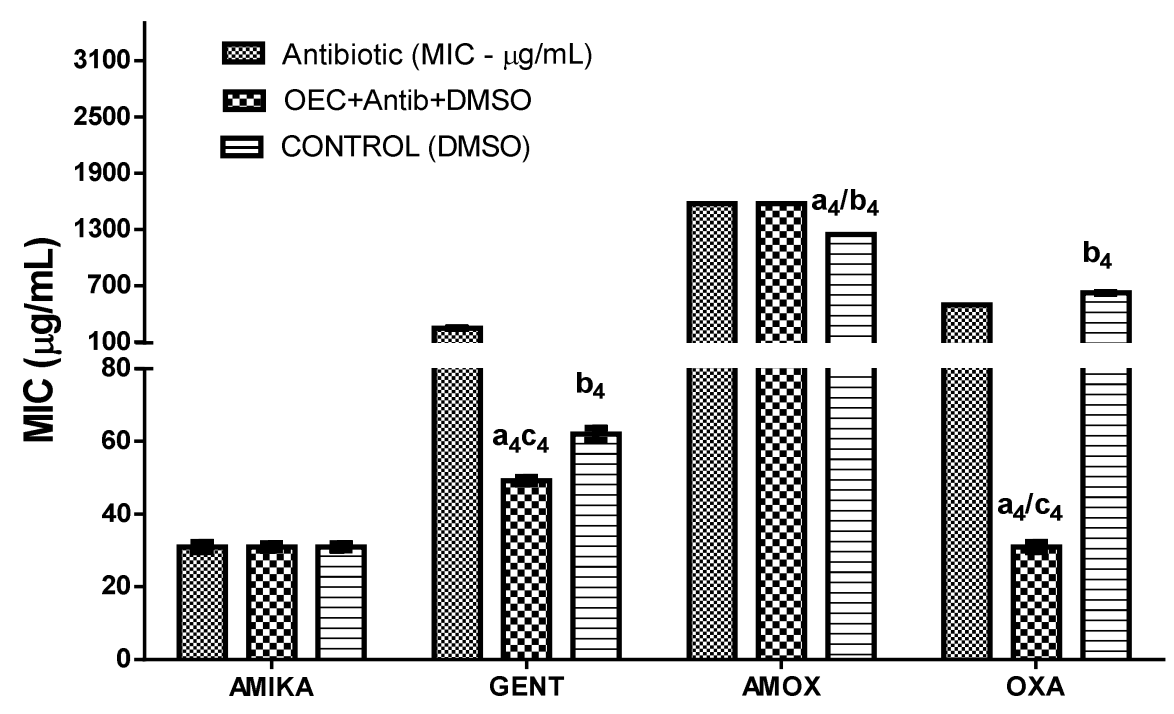

One Way ANOVA, followed by the Turkey test: ${ }^{\mathrm{a} 4} \mathrm{p}<0.0001$ vs antibiotic; ${ }^{\mathrm{b} 4} \mathrm{p}<0.0001$ vs EOC + antibiotic + DMSO; ${ }^{\mathrm{c} 4} \mathrm{p}<$ 0.0001 vs Control (DMSO). Amika-Amikacin; Gent-Gentamicin; Amox-Amoxicillin; Oxa-Oxacillin.

B

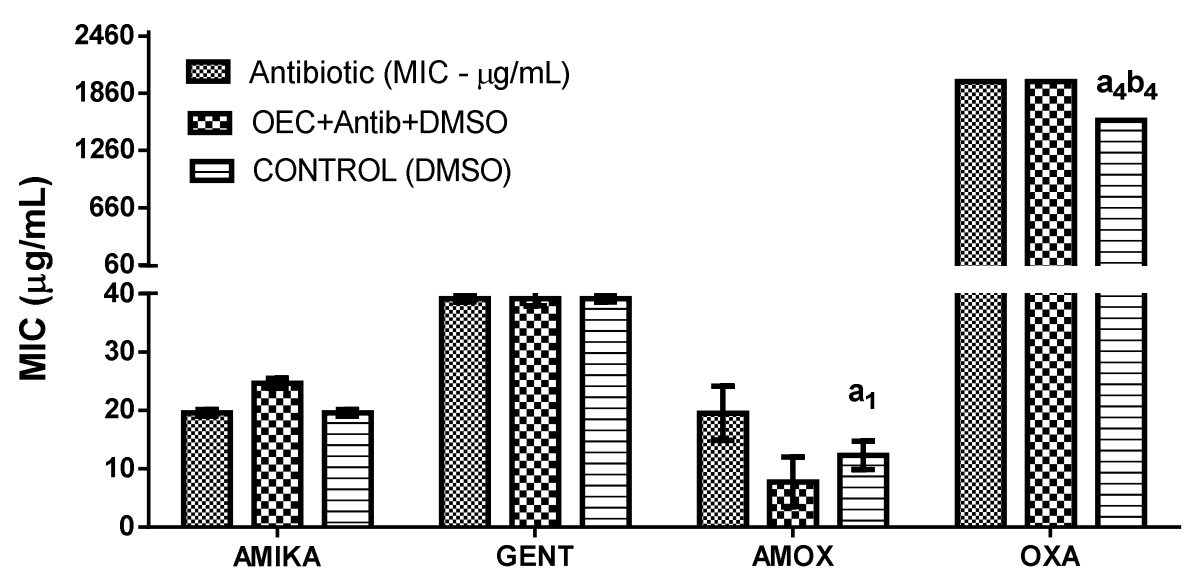

One Way ANOVA, followed by the Turkey test: ${ }^{\text {al }} \mathrm{P}<0.05$ vs antibiotic; ${ }^{\mathrm{a} 4} \mathrm{p}<0.0001$ vs antibiotic; ${ }^{\mathrm{b4}} \mathrm{p}<0.0001$ vs EOC + antibiotic + DMSO. Amika-Amikacin; Gent-Gentamicin; Amox-Amoxicillin; Oxa-Oxacillin.

C



One Way ANOVA, followed by the Turkey test: ${ }^{\mathrm{a} 2} \mathrm{P}<0.05$ vs antibiotic; ${ }^{\mathrm{a}} \mathrm{p}<0.0001$ vs antibiotic; ${ }^{\mathrm{c}} \mathrm{p}<0.0001$ vs Control (DMSO). Amika-Amikacin; Gent-Gentamicin; Amox-Amoxicillin; Oxa-Oxacillin.

Figure 1. Modulatory activity of antibiotics of the essential oil of Croton rhamnifolioides leaves (EOC) in association with aminoglycosides and $\beta$-lactam against Escherichia coli (A), Pseudomonas aeruginosa (B) and Staphylococcus aureus (C). 
Several natural products utilized as therapeutic treatment possess an expressive synergistic action with antibiotics (SOUSA et al, 2011; FIGUEREDO et al, 2013). This potentiation is promoted by these products through an increase in their activity, altering the cellular membrane permeability making the absorption of antibiotics more permeable and causing loss of vital cellular contents (BURT et al, 2004). In this manner, these compounds are denominated modifiers of antibiotic activity (RODRIGUES et al, 2009; TINTINO et al, 2013).

The use of essential oils as antimicrobial agents offers a low risk in development of microbial resistance since their chemical complexity hamper the appearance of resistance because their composition can act via different mechanisms of interaction with bacteria (BERTINI et al, 2005; BAKKALI et al, 2008).

In studies undertaken by COSTA et al. (2013), bacterial activity of the essential oil of Croton rhamnifolioides leaves was revealed against several bacteria, amongst them $S$. aureus and $E$. Coli presenting a MIC of $5-1 \mu \mathrm{L} / \mathrm{mL}$ and $20-1$ $\mu \mathrm{L} / \mathrm{mL}$ respectively via the gas contact method. This result was attributed to the presence of 1,8-cineol, the major constituent. Other studies show that this compound when isolated possesses antimicrobial activity (OKE et al, 2009; ALT-OVAZZOU et al, 2011). However, the EOC did not present antibacterial activity via direct contact in microdilution trials, which can be attributed to chemical differences in its composition when compared to the previous study, such as the difficulty of terpene penetration in the presence of DMSO (BOTREL et al, 2010).

In the present study both the Gram-positive Staphylococcus aureus and the Gram-negative Escherichia coli and Pseudomonas aeruginosa, were susceptible to antimicrobial drugs associated with EOC of the aminoglycosides and $\beta$-lactam penicillin groups. The Gram-positive bacteria are more susceptible to modulation than the Gramnegatives. This occurs because the Gram-negative bacteria are surrounded by a resistant external membrane composed of phospholipids, proteins and lipopolysaccharides that provide a hydrophilic surface acting as a barrier conferring impermeability to some antibiotics (NIKAIDO, 2003; KOJIMA; NIKAIDO, 2013; VARGIU; NIKAIDO, 2012).

The aminoglycoside groups inhibit protein synthesis by binding the 30 s ribosomal subunit causing death of the bacteria, acting against Gramnegative bacteria and presenting a positive synergism in association with other antibiotics in the treatment of infections for Gram-positive agents (TRABULSI; ALTERTHUM, 2008). The $\beta$-lactam penicillin antibacterials are inhibitors of the bacterial wall synthesis by inhibiting the enzyme transpeptidase, consequently disrupting crossligation of the polymers (MAJIDUDDIN et al, 2002). The synergistic action of the oil with these groups of antibiotics can involve the intensification of the action of the drug by direct or indirect destruction of the bacterial peptidoglycan cellular wall, permitting the entry of antibacterials such as aminoglycosides (HEMAISWARYA et al, 2008).

Among other mechanisms whereby the oil can intensify the action of antibacterial drugs, the increase in membrane permeability stands out permitting a greater entry of the remedy, impeding the bacterial efflux system, inhibiting the production of aminoglycosides inactivating enzymes and impeding the action of $\beta$-lactamase (SHELDON, 2005).

The sesquiterpene spathulenol presents important biological activity, such as antibacterial properties and moderate cytotoxic activity (LIMBERGER et al, 2004). This terpene was also identified in studies carried out by MEDEIROS et al. (2003), relating antimicrobial activity against $S$. aureus, $S$. epidermidis and $P$. aeruginosa. CONSTANTIN et al. (2001), identified $\alpha$ and $\beta$ pinene, bicyclogermacrene, $\quad \beta$-caryophyllene, spathulenol and germacrene-D in Piper cernuum and proved its antimicrobial action against $S$. aureus and Candida albicans, demonstrating more evidence to the possible involvement of these compounds in the modulatory action of Croton rhamnifolioides.

In the modulation of antifungals, a subinhibitory concentration of $8 \mu \mathrm{g} / \mathrm{mL}$ determined by MIC/8 was utilized. It was observed that in the modulation against Candida tropicalis the EOC did not present any significant effect. On the other hand, its effect was significant against Candida albicans when in association with Nystatin, providing a reduction of $68.47 \%$ in the necessary concentration for the inhibition of the microorganism (Figure $2 \mathrm{~A}$ and $\mathrm{B}$ ).

Essential oils can present action against yeast as well as filamentous fungi (PRASHAR et al, 2003). Many antifungals utilized for the treatment of infections by Candida produce numerous side effects and frequently induce fungal resistance, especially in immunocompromised patients (FICA, 2004). The synergistic action observed by the EOC can be important to increase the antifungal effect as well as decrease resistance. 
A

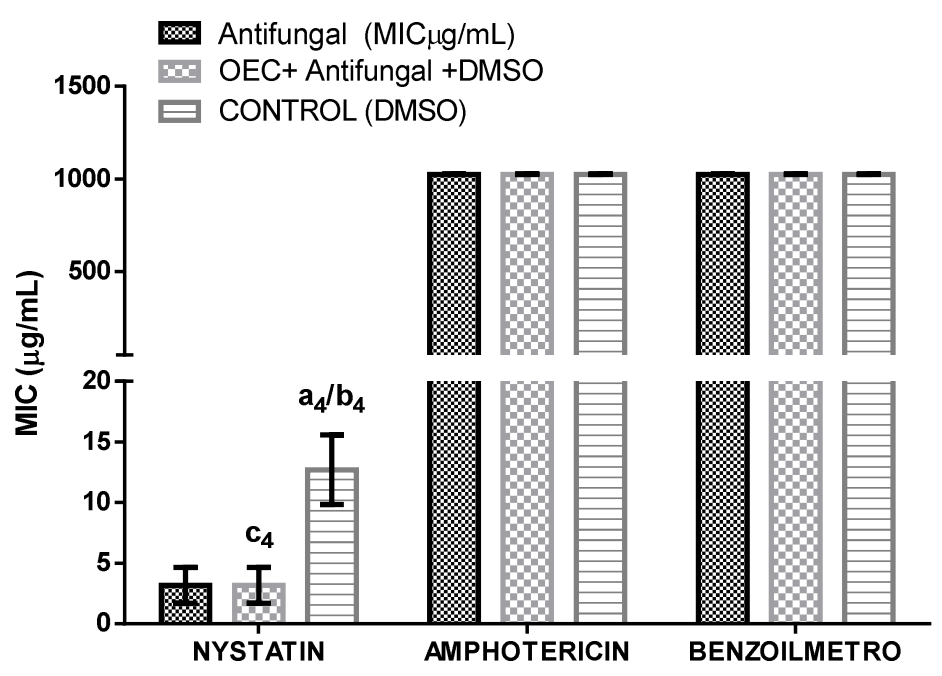

One Way ANOVA, followed by the Turkey test: ${ }^{a 4} \mathrm{p}<0.0001$ vs antibiotic; ${ }^{\mathrm{b}} \mathrm{p}<0.0001$ vs EOC + antibiotic + DMSO; ${ }^{c 4} \mathrm{p}<0.0001$ vs Control (DMSO). Benzoilm- Benzoylmetronidazol.

B



One Way ANOVA, followed by the Turkey test: ${ }^{\mathrm{a} 3} \mathrm{p}<0.001$ vs antibiotic; ${ }^{\mathrm{b} 4} \mathrm{p}<0.0001 \mathrm{vs}$ EOC + antibiotic + DMSO; ${ }^{c 4} \mathrm{p}<0.0001$ vs Control (DMSO). Benzoilm- Benzoylmetronidazol.

Figure 2. Modulatory activity of antifungals of the essential oil of Croton rhamnifolioides leaves in association with Nystatin, Amphotericin and Benzoylmetronidazol against Candida tropicalis (A), and Candida albicans

Several species of the Croton genus have demonstrated antifungal activity, for example, Croton zehntneri, Croton nepetaefolius and Croton argyrophyloides (FONTENNELE et al, 2007). Furthermore, many species that present the sesquiterpene spathulenol as one of the major constituents of its essential oil also present considerable antifungal activity against Candida albicans (RAGGI, 2008; CONSTANTIN et al, 2001), Candida ssp. (NASCIMENTO, 2008), Trichophyton tonsurans, Trichophyton rubrum, Trichophyton menthagrophytes, Epidermophyton floccosun, Microsporum gypseum, Microsporum canis, Microsporum nanum (FLACH et al, 2002) and Aspergillus nigris (BORGES, 2012).

Nystatin binds to steroids existing in the cellular membrane, leading to defects in the membrane, alterations in its permeability and consequently extravasation of the cytoplasmic contents and fungal cellular death (WANNMACHER; FERREIRA, 2007).

The MIC reduction of the antifungals in the presence of the natural product indicates that the same is capable of acting synergistically, favoring the antifungal effect. It is speculated that the mechanism of action of terpenes in microorganisms can be associated with the disruption in the membrane by the lipophilic compounds (COWAN, 
1999). The oil in study, may have acted through a potentiation of the antifungal action of the polyene Nystatin in its ability to increase the membrane permeability, where the synergism presented can be associated with the major compounds, representing a significant result for "shotgun herbs" where a combination between the natural product and synthetic product collaborate in an agonist manner (WAGNER; ULRICH-MERZENICH, 2009). antimicrobial activity, however, a significant modulatory effect was observed when the oil was associated with aminoglycosides and $\beta$-lactam antibiotics against Escherichia coli, Pseudomonas aeruginosa and Staphylococcus aureus, and in the association with polyene antifungals against the Candida albicans strain. Its activity being associated with the presence of its predominant compounds spathulenol and 1,8-cineol.

\section{CONCLUSION}

$\begin{array}{ccc}\text { The essential oil of } & \begin{array}{c}\text { Croton } \\ \text { rhamnifolioides did not present any significant }\end{array}\end{array}$

RESUMO: Croton rhamnifolioides is é um arbusto conhecido popularmente como "quebra-faca" e utilizado como chá ou infusão para o tratamento de problemas gastro-intestinais como úlceras, desconforto gástrico, vômitos e diarréias hemorrágicas. O objetivo deste trabalho foi avaliar a composição química do óleo essencial das folhas de Croton rhamnifolioides (OEC), atividade antibacteriana, moduladora da resistência bacteriana, contra linhagens bacterianas de Escherichia coli, Staphylococcus aureus e Pseudomonas aeruginosa e, atividade antifúngica contra Candida albicans, $C$. krusei e $C$. tropicalis. A composição química foi determinada através de Espectroscopia de Massas acoplada a Cromatografia Gasosa (EM/CG), enquanto as atividades antimicrobianas e moduladoras foram determinadas pelo método de microdiluição. A composição química do OEC revelou a presença de 21 compostos, sendo os principais o Espatulenol $(22,46 \%)$ e 1,8-cineol (18,32\%). A atividade antimicrobiana não foi considerada significativa apresentando MIC $>1024$ $\mu \mathrm{g} / \mathrm{mL}$, contudo, foi observado um sinergismo quando o óleo essencial foi associado com aminoglicosídios, $\beta$-lactâmicos e antifúngicos poliênicos.

PALAVRAS-CHAVE: Croton rhamnifolioides. Modulação. Óleo essencial. Terpenos.

\section{REFERENCES}

ALCÂNTARA, J. M.; KAZUMY, K.; YAMAGUCHI, D. L.; ROCHA, J.; SILVA D. A. Chemical composition and biological activity of the essential oils of leaves and stalk of Rhodostemono daphne parvifolia Madrinan (Lauraceae). Acta Amazonica, v. 40, p. 567-571, 2010. https:/doi.org/10.1590/S0044-59672010000300016

ALT-OVAZZOU, A.; CHERRAT, L.; ESPINA, L.; LARAN, S.; ROTA, C.; PAGAN, R. The antimicrobial activity of hydrophobic essential oil constituents acting alone or in combined process of food preservation. Innovative Food Science e Emerging Technologies, v. 12, p. 320-390, 2011.

https:/doi.org/10.1016/j.ifset.2011.04.004

ALVARENGA, A. L.; SCHWAN, R. F.; DIAS, D. R.; SCHWAN-ESTRADA, K. R. F.; BRAVOMARTINS, C. E. C. Antimicrobial activity of plant extracts over human pathogenic bacteria. Revista Brasileira de Plantas Medicinais, v. 9, p. 86-91, 2007.

ALVES, T. M. A.; SILVA, A. F.; BRANDÃO, M.; GRANDI, T. S. M.; SMÂNIA, E. F.; SMÂNIA JR., A.; ZANI, C. L. Biological screening of Brazilian medicinal plants. Memórias de Instituto Oswaldo Cruz, v. 95, p. 367-373, 2000. https:/doi.org/10.1590/S0074-02762000000300012

AMARAL, J. F. Anti-inflammatory, antinociceptive and gastro-protective activity of the essential oil of Croton sonderianus Muell. Arg. Fortaleza: UFC, 2004.

BAKKALI, F.; AVERBECK, S.; AVERBECK, D.; WAOMAR, M. Biological effects of essential oils-a review. Food Chemistry and Toxicology, v. 46, p. 446-475, 2008. https:/doi.org/10.1016/j.fct.2007.09.106 
BERTINI, L. M.; PEREIRA, A. F.; OLIVEIRA, C. L. L.; MENEZES, E. A.; MORAIS, S. M.; CUNHA, F. A.; CAVALCANTI, E. S. B. Sensibility profile of bacteria against essential oils of some plants of the Northeast of Brazil. Infarma, v. 17, p. 80-83, 2005.

BLAIR, J. M. A.; WEBBER, M. A.; BAYLAY, A. J.; OGBOLU, D. O.; PIDDOCK, L. J. V. Molecular mechanisms of antibiotic resistance. Nature Reviews in Microbiology, v. 13, p. 42-51, 2014. https:/doi.org/10.1038/nrmicro3380

BORGES, L. S. Potential antioxidant, essential oil and antifungal activity of jambu plants (Spilanthes oleracea), cultivated under organic and conventional fertilization. Botucatu: Unesp, 2012.

BOTREL, P. P.; PINTO, J. E. B. P.; ARAÚJO, A. C. C.; FIGUEIREDO, F. C.; CHAGAS, J. H.;

BERTOLUCCI, S. K. V. Volatile oil content of field mint hits collected from different locations in the South of Minas Gerais. Hortiultura Brasileira, v. 28, p. 2, 2010.

BRITO, A. F. R. Analyses of seasonal variation and antifungal and antimicrobial activity in essential oils of Ocotea porosa (Nees) Barroso e Nectandra megapotamica (Spreng.) Menz. São Paulo: USP, 2009.

BURT, S. Essential oils: their antibacterial properties and potential applications in food: a review. International Journal of Food Microbiology, v. 94, p. 223-253, 2004.

https:/doi.org/10.1016/j.ijfoodmicro.2004.03.022

CALDAS, G. F. R.; COSTA, I. M. A.; SILVA, J. B. R.; NÓBREGA, R. F.; RODRIGUES, F. G.; COSTA, J. G. M.; WANDERLEY, A. G. Antiulcerogenic activity of the essential oil of Hyptis martiussi Beth ( Lamiaceae). Journal of Ethnopharmacology, v. 137, p. 886-892, 2011.

https:/doi.org/10.1016/j.jep.2011.07.005

CAMPOS, M. C. O.; SALOMÃO, K.; CASTRO-PINTO, D. B.; LEON, L. L.; BARBOSA, H. S.; MACIEL, M. A. M. Croton cajucara crude extract and isolated terpenes: activity on Trypanosoma cruzi. Parasitology Research, v. 107, p. 1193-1204, 2010. https:/doi.org/10.1007/s00436-010-1988-6

CLSI-Clinical and Laboratory Standards Institute. Reference Method for Broth Dilution Antifungal Susceptibility Testing of Yeasts. Approved Standard M27-A3, 3rd ed. Wayne: NIH, 2008.

CONSTANTIN, M. B.; SARTORELLI, P.; LIMBERGER, R.; HENRIQUES, A. T.; STEPPE, M.; FERREIRA, M. J. P.; OHARA, M. T.; EMERENCIANO, V. P.; KATO, M. J. Essential oils from Piper cernuum and Piper regnellii: Antimicrobial activities and analysis by GC/MS and ${ }^{13} \mathrm{C}-\mathrm{NMR}$. Planta Medica, v. 67, p. 771-773, 2001. https:/doi.org/10.1055/s-2001-18363

COSTA, A. C. V.; MELO, G. F. A.; MADRUGA, M. S.; COSTA, J. G. M.; GARINO JUNIOR, F.; QUEIROGA NETO, V. Chemical composition and antibacterial activity of essential oil of a Croton rhamnifolioides leaves Pax \& Hoffm. Ciências Agrárias, v. 34, p. 2853-2864, 2013.

https:/doi.org/10.5433/1679-0359.2013v34n6p2853

COUTINHO, H. D. M.; COSTA, J. G. M.; SIQUEIRA-JUNIOR, J. P.; LIMA, E. O. In vitro Staphylococcal activity of Hyptis martiusii Benth against methicillin resistant Staphylococcus aureus-MRSA strains. Revista Brasileira de Farmacognosia, v. 18, p. 670-675, 2008. https:/doi.org/10.1590/S0102-695X2008000500005

COWAN, M. M. Plant products as antimicrobial agents. Clinical Microbiology Reviews, v. 12, p. 564-582, 1999.

COX, S. D.; MANN, C. M.; MARHAM, J. L. The mode of antibacterial action of the essential oil of Melaleuca alternifolia. Journal of Applied Microbiology, v. 88, p. 365-371, 2000. 
DUARTE, M. C. T. Atividade antimicrobiana de plantas medicinais e aromáticas utilizadas no Brasil. MultiCiência, v. 7, p. 17, 2006.

FICA, A. C. Tratamiento de Infecciones Fungicas Sistémicas- Primeira Parte: Fluconazol, Itraconazol y Voriconazol. Revista Chilena de Infectologia, v. 21, p. 26-38, 2004. https:/doi.org/10.4067/S071610182004000100004

FIGUEREDO, F. G.; FERREIRA, E. O.; LUCENA, B. F. F.; TORRES, C. M. G.; LUCETTI, D. L.; LUCETTI, E. C. P.; SILVA, J. M. F. L.; SANTOS, F. A. V.; MEDEIROS, C. R.; OLIVEIRA, G. M. M.; COLARES, A. V.; COSTA, J. G. M.; COUTINHO, H. D. M.; MENEZES, I. R. A.; SILVA, J. C. F.; KERNTOPF, M. R.; FIGUEIREDO, P. R. L.; MATIAS, E. F. F. Modulation of the antibiotic activity by extracts from Amburana cearensis A. C. Smith and Anadenanthera macrocarpa (Benth.) Brenan. Biomed Research International, v. 1013, p. 1 - 5, 2013. https:/doi.org/10.1155/2013/640682

FLACH, A.; GREGEL, B.; SIMIONATTO, E.; DA SILVA, U. F.; ZANATTA, N.; MOREL, A. F.; LINARES, C. E.; ALVES, S. H. Chemical analysis and antifungal activity of the essential oil of Calea clemtidea. Planta Medica, v. 68, p. 836-838, 2002. https:/doi.org/10.1055/s-2002-34414

FONTENNELE, R. O. S.; MORAIS, S. M.; BRITO, E. H. S.; KERNTOPF, M. R.; BRILHANTE, R. S. N.; CORDEIRO, A.; TOMÉ, A.R.; QUEIROZ, M. G. R. Chemical composition, toxicological aspects and antifungal activity of essential oil from Lippia sidoides cham. Journal of Antimicrobial Chemotherapy, v. 59, p. 934-940, 2007. https:/doi.org/10.1093/jac/dkm066

HAIDA, K. S.; PARZIANELLO, L.; WERNER, S.; GARCIA, D. R.; INÁCIO, C. V. In vitro Analysis of the antimicrobial activity of eight medicinal plant species. Arquivos de Ciencias da Saude Unipar, v. 11, p. 185192, 2007.

HEMAISWARYA, S.; KRUTHIVENTI, A. K.; DOBLE, M. Synergism between natural products and antibiotics against infectious diseases. Phytomedicine, v. 15, p. 639 652, 2008.

JAVADPOUR, M. M.; JUBAN, M. M.; LO, W. C.; BISPO, S. M.; ALBERTY, J. B.; COWEL, M. S.; BECKER, C. L.; MCLAUGHLIN, M. L. De Novo antimicrobial peptides with cellular toxicity of low mammals. Journal of Medicinal Chemistry, v. 39, p. 3107-3113, 1996. https:/doi.org/10.1021/jm9509410

KOJIMA, S.; NIKAIDO, H. Permeation rates of penicillins indicate that Escherichia coli porins function principally as nonspecific channels. Proceedings of National Academy of Sciences USA, v. 110, p. E2629E2634, 2013. https:/doi.org/10.1073/pnas.1310333110

LAMBERT, P. A. Cellular impermeability and uptake of biocides and antibiotics in Gram-positive bactéria and mycobacteria. Journal of Applied Microbiology, vol. 92, p. 46S-54S, 2002. https:/doi.org/10.1046/j.13652672.92.5s1.7.x

LAZARINI, C. A., UEMA, A. H., BRANDÃO, G. M., GUIMARÃES, A. P., BERNARDI, M. M. Croton zehntneri essential oil: effects on behavioral models related to depression and anxiety. Phytomedicine, v. 7, p. 477-481, 2000. https:/doi.org/10.1016/S0944-7113(00)80033-1

LIMA, I. O.; OLIVEIRA, R. A. G.; LIMA, E. O.; FARIAS, N. M. P.; SOUZA, E. L. Antifungal activity of essential oils against Candida species. Revista Brasileira de Farmacognosia, v. 16, p. 197-201, 2006.

LIMBERGER, R. P.; SOBRAL, M.; HENRIQUES, A. T.; MENUT, C.; BESSIÈRE, J. M. Volatile oils of the Myrcia species native to Rio Grande do Sul. Química Nova, v. 27, p. 916-919, 2004.

https:/doi.org/10.1590/S0102-695X2006000200011

MAJIDUDDIN, F. K.; MATERON, I. C.; PALZKILL, T. G. Molecular analysis of beta-lactamase structure and function. International Journal of Medical Microbiology, v. 292, p. 127-137, 2002. 
https:/doi.org/10.1078/1438-4221-00198

MEDEIROS J. R.; CAMPOS, L. B.; MENDONÇA, S. C.; DAVIN, L. B.; LEWIS, N. G. Composition and antimicrobial activity of the essential oils from invasive species of the Azores, Hedychium gardnerianum and Pittosporum undulatum. Phytochemistry, v. 64, p. 561-565, 2003. https:/doi.org/10.1016/S00319422(03)00338-8

MORAIS, S. M.; JÚNIOR, F. E. A. C.; SILVA, A. R. A.; NETO, J. S. M. Antioxidant activity of the essential oils of the Croton species of the Northeast of Brazil. Química Nova, v. 29, p. 907-910, 2006.

https:/doi.org/10.1590/S0100-40422006000500004

NASCIMENTO, K. M. Chemical composition and antifungal activity of the essential oils of the Piper species against Candida spp strain. Fortaleza:UECE, 2011.

NIKAIDO, H. Molecular basics of bacterial outer membrane permeability revisited. Microbiology and Molecular Biology Reviews, v. 4, p. 593-656, 2003. https:/doi.org/10.1128/MMBR.67.4.593-656.2003

OKE, F.; ASLIM, B.; OZTURK, S.; ALTUNDAG, S. Essential oil composition, antimicrobiaand antioxidant activities of Satuneja cuneifolia Ten. Food Chemistry, v. 112, p. 874-879, 2009.

https:/doi.org/10.1016/j.foodchem.2008.06.061

OLIVEIRA, A. C.; LEAL-CARDOSO, J. H.; SANTOS, C. F.; MORAIS, S. M.; SOUZA, A. N. C. Antinociceptive effects of the essential oil of Croton zehntneri in mice. Journal of Medical and Biological Research, v. 34, p. 1411-1474, 2001. https:/doi.org/10.1590/S0100-879X2001001100016

PRASHAR, A.; HILI, P.; VENESS, R. G.; EVANS, C. S. Antimicrobial action of palmarosa oil (Cymbopogon martinii) on Saccharomyces cerevisiae. Phytochemistry, v. 63, p. 569-575, 2003.

https:/doi.org/10.1016/S0031-9422(03)00226-7

RAGGI, L. Study of the chemical composition and biological activities of volatile oils of the Lauraceae species, in different times of the year. São Paulo: USP, 2008.

RAMOS, J. M. O.; SANTOS, C. A.; SANTANA, D. G.; SANTOS, D. A.; ALVES, P. B.; THOMAZZI, S. M. Chemical constituentsand potential anti-inflammatory activity of the essential oil from the leaves of Croton argyrophyllus. Brazilian Journal of Pharmacognosy, v. 23, p. 644-650, 2013.

RANDAU, K. P. Pharmacognosy study (Pharmacobotanical and Pharmacochemical) and biological activity of Croton rhamnifolius H.B.K. e Croton rhamnifolioides Pax \& Hoffam. (Euphorbiaceae). Recife: UFPE, 2001.

RODRIGUES, F. F. G.; COSTA, J. G. M.; COUTINHO, H. D. M. Synergy effects of the antibiotics gentamicin and the essential oil of Croton Zehntneri. Phytomedicine, v. 16, p. 1052-1055, 2009. https:/doi.org/10.1016/j.phymed.2009.04.004

ROSA, M. D. S. S.; MENDONÇA-FILHO, R. R.; BIZZU, H. R.; RODRIGUES, I. D. H.; SOARES, R. M. A.; SOUTO-Padrón, T. Antileishmanialactivy of a linalool- rich essential from Croton cajucara. Antimicrobial Agents and Chemotherapy, v. 47, p. 1895- 1901, 2003. https:/doi.org/10.1128/AAC.47.6.1895-1901.2003

SANTOS, R. L.; GUIMARAES, G. P.; NOBRE, M. S. C.; PORTELA, A. S. Analysis over the phytotherapy as integrated practice in the Sistema Único de Saúde. Revista Brasileira de Plantas Medicinais, v. 13, p. 486491, 2011.

SHELDON, A. T. Sheldon Antibiotic resistance: a survival strategy. Clinical Laboratory Science, v. 18, p. 170-180, 2005. 
SILVA, V. A., OLIVEIRA, C. R. M., FREITAS, A. F. R., COSTA, M. R. M., PESSÔA, H. L. F., PEREIRA, M. S. F. Antimicrobial efficacy of the extract extract of Croton sonderianus Mull. On bacteria that cause dental caries. Revista de Odontologia UNESP, v. 40, p. 69-72, 2011.

SOUSA, E. O.; BARRETO, F. S.; RODRIGUES, F. F. G.; COSTA, J. G. M. Antibacterial activity and interference of Lantana camara Linn and Lantana montevidensis Briq in the resistance against aminoglycosides. Revista Brasileira de Otorrinolaringologia, v. 67, p. 845-851, 2011.

SOUZA, M. A. A.; SOUZA, S. R.; VEIGA JR, V. F.; CORTEZ, J. K. P. C.; LEAL, R. D. S.; DANTAS, T. N. C. Chemical composition of the oil of Croton cajucara and determination of its fungicidal properties. Revista Brasileira de Famacognosia, v. 16, p. 599-610.

TINTINO, S. R.; GUEDES, G. M. M.; CUNHA, F. A. B.; SANTOS, K. K. A.; FERREIRA, E. F. M.; MORAIS-BRAGA, M. F. B.; ANDRADE, J. C.; SOBRAL-SOUZA, C. E.; FREITAS, M. A.; ALENCAR, L. M. B.; COSTA, J. G. M.; COUTINHO, H. D. M. In vitro evaluation of antimicrobial activity and modulating the etanol and hexane extracts of Costus arabicus bulb. Bioscience Journal, v. 29, p. 732-738, 2013.

TOMAZONI, E. Z.; PAULETTI, G. F.; RIBEIRO, R. T. S.; SCHWAMBACH, J. In vitro Antifungal activity of the essential oils of Pinus elliottii and Pinus taeda against the tomato pathogenic fungus. Cadernos Pedagogicos, v. 11, p. 68-77, 2014.

TRABULSI, L. R.; ALTERTHUM, F. Microbiologia, 5a ed. São Paulo:Ed. Atheneu, 2008.

VARGIU, A. V.; NIKAIDO H. Multidrug binding properties of the AcrB efflux pump characterized by molecular dynamics simulations. Proceedings of National Academy of Sciences USA, v. 109, p. 2063720642, 2012. https:/doi.org/10.1073/pnas.1218348109

VICTORIA, F. N. New Bioactive Organoselenium Compounds: Studies of Antimicrobial Action Against Important Pathogens in Foods. Pelotas: UFPel, 2010.

VIOLANTE, G.; ZERROUK, N.; RICHARD, I.; PROVOT, G.; CHAUMEIL, J. C.; ARNAUD, P. Evaluation of the Cytotoxicity Effect of Dimethyl Sulfoxide (DMSO) on Caco2/TC7 Colon Tumor Cell Cultures.

Biological \& Pharmaceutical Bulletin, v. 25, p. 1600-1603, 2002. https:/doi.org/10.1248/bpb.25.1600

WAGNER, H.; ULRICH-MERZENICH G. Synergy research: approaching a new generation of phytopharmaceuticals. Phytomedicine, v. 16, p. 97-110, 2009. https:/doi.org/10.1016/j.phymed.2008.12.018

WANNMACHER, L. Antifungals. In: WANNMACHER, L.; FERREIRA, M. B. C. Clinical Pharmacognosy for dentists. $3^{\mathrm{a}}$ ed. Rio de Janeiro: Guanabara Koogan, 2007.

ZIAEI, A.; RAMEZANI, M.; WRIGHT, L.; PAETZ, C.; SCHNEIDER, B.; AMIRGHOFRAN, Z. Identification of Spathulenol in Salvia mirzayanii and the Immunomodulatory effects. Phytotherapy Research, v. 25, p. 557-562, 2011. https:/doi.org/10.1002/ptr.3289 